\title{
REVIEW: COMPARISON OF ULTRASONICALLY AIDED ZINC BENEFICIATION BY MECHANICAL FLOTATION AND COLUMN FLOTATION CELL
}

\author{
Ugur Ulusoy \\ Division of Mineral Processing \\ Department of Mining Engineering \\ uulusoy@cumhuriyet.edu.tr \\ Hulya Kurşun \\ Department of Material and Metallurgical Engineering ${ }^{l}$ \\ hkursun@cumhuriyet.edu.tr \\ ${ }^{1}$ Sivas Cumhuriyet University \\ Sivas, Turkey, TR-58140
}

\begin{abstract}
Zinc is a key beneficiary of economic development for the developing countries. While the global zinc mine production in 2019 was recorded as 13 million tons, the value of zinc mined in 2019, based on zinc contained in concentrate, was about \$2.1 billion. Sphalerite or zinc blende $(\mathrm{ZnS})$, which is the main source of zinc, provides more than $90 \%$ of zinc productions today. Beneficiation is usually carried out by flotation to produce marketable concentrates ( $45-55 \% \mathrm{Zn})$. The flotation, which is the most widely used separation process at fine sizes for the concentration of low grade complex $\mathrm{Pb}-\mathrm{Cu}-\mathrm{Zn}$ ores plays an important role in the global economy. In any concentration plant employing flotation technique huge quantity of ores are being processed. Thus, any increments in the flotation recovery are important to get higher profits and to ensure that resources are utilized optimally. In this review, a comparative evaluation was made between mechanical flotation (MF) [1] and column (CF) [2] cells with or without ultrasonic pre-treatment (UP) for zinc recovery from lead-zinc-copper ore and the effect of UP on the MF and CF experiments were investigated at the optimized conditions. When compared with the optimized parameters, UP increased zinc grade and recovery for both MF and CF techniques as supported by XRD patterns. Besides, the best zinc grade and recovery was obtained by UP with CF technique. So that, sphalerite mineral can be effectively beneficiated to produce saleable zinc concentrate product and UP with CF will lead to a higher metallurgical gains and improvements to Net Smelter Return (NSR). This positive effect of ultrasound, which is safe and eco-friendly, on the zinc flotation by both mechanical cell and column cell regarding zinc grade and recovery is in good agreement with the previous published works in the literature.
\end{abstract}

Keywords: Zinc, mechanical flotation, column flotation, flotation, grade, recovery, ultrasonic treatment, XRD, cavitation.

DOI: $10.21303 / 2461-4262.2021 .001608$

\section{Introduction}

The economic growing of countries mostly contingent on transforming their underground wealth into advantageous commodities [3]. Zinc is one of those resources, which is a mild, shiny silvery to steel-grey metal that often occurs in the presence of other minerals of copper, lead, and silver. It is essential to modern living, and, in tonnage produced, stands fourth among all metals in world production - being exceeded only by iron, aluminum, and copper. Zinc has unique chemical characteristics such as brittle until heated above $100{ }^{\circ} \mathrm{C}$, then becomes malleable, stops oxidation and corrosion of underlying metal when applied as a coating (galvanization) and becomes strong as steel but flexible when combined with aluminum. These make zinc an indispensable element to life and industry and zinc uses range from metal products to rubber and medicines especially automotive, machinery manufacturing, construction metals and communications. Therefore, it is a critical element in a broad sort of products including coatings, castings, alloys, mill products and chemicals and other specialist applications [4]. About three-fourths of zinc used is consumed as metal, mainly as a coating to protect iron and steel from corrosion (galvanized metal), as alloying metal to make bronze and brass, as zinc-based die casting alloy, and as rolled zinc [5]. As reported by USGS [6] Global zinc mine production in 2019 was estimated to be 13 million tons, a $4 \%$ increase from that of 2018 . It is of great significant to exploit 
the low-grade zinc oxide ores and improve the utilization ratio of the zinc natural resources. Zinc minerals are generally associated with other metal minerals, the most common associations in ores being zinc-lead, lead-zinc, zinc-copper, copper-zinc, zinc-silver, or zinc only. Run-ofmine zinc-containing ores must be enriched before smelting and refining because of their low zinc content.

Sphalerite is one of the sulfide minerals (frequently found together along with galena and chalcopyrite in complex $\mathrm{Pb}-\mathrm{Cu}-\mathrm{Zn}$ ores) separated from gangue minerals by conventional flotation techniques to produce marketable zinc concentrates containing $45-55 \% \mathrm{Zn}$. Since huge quantity of ores are being processed by flotation, any increments in the flotation recovery does matters and cause remarkable profits [7]. The pulp must be conditioned before flotation to make valuable mineral hydrophobic. Since conditioning has a direct impact on the pulp residence time and plant throughput, various ways of facilitating conditioning process were investigated [8-11]. One of the ways of applying ultrasonic energy into pulp is using an ultrasonic cleaning bath [12].

As it is well known, ultrasound is characterized with sound waves having frequencies greater than $20 \mathrm{kHz}$ [13] and it plays superior role in the mineral surface. Frequencies which are measured in thousands of cycles per second $(\mathrm{kHz})$ are produced by ultrasound transducers attached to the bottom, and in some cases also the sides, of the ultrasonic cleaning bath. The transducers are excited by the unit's ultrasonic generator to produce millions of microscopic bubbles in the solution that implode on contact with parts. This implosion is known as «cavitation» [14]. while hydrodynamic cavitation is defined as a process by which bubbles are produced when the local pressure is diminished to a level that destroy a liquid-liquid or solid-liquid interface in a flowing film [15]. The ultrasonic treatment $(20-40 \mathrm{kHz})$ is based on the cavitation causing hydrodynamic shear [16] and giving rise to the dispersion of aggregates [17].

The size at which a particle becomes a «fine particle» is described as the size finer than the minimum for optimal flotation recovery [18]. Two primary approaches such as increasing of the particle size and decreasing of the bubble size were used to improve the fine particle recovery in the flotation process [19]. Fine particles are best floated with small bubbles, and hydrodynamic conditions inside a mechanical flotation (MF) cell are not appropriate for fine particle flotation. Column flotation (CF) provides higher concentration, more productivity, less cost of production, and better control of plant than the conventional MF mainly due to the long retention time of the solid particles, counter current flow, contact pattern and the wash water added at the top of the froth [20-22]. Moreover, CF has an advantage in recovering of fine particles than MF due to more favorable conditions and smaller bubbles. The small bubbles can be produced by hydrodynamic cavitation [23].

In the mineral industry ultrasound has been recently utilized as a positive element in successful manner. For example, iron elimination on the silica sand can be removed with efficiency by ultrasound than by mechanical scrubbing. Moreover, the combination of ultrasound and solutions of some chemicals like water glass, soda and sodium pyrophosphate, can remove iron faster owing to the synergistic effect [24-26]. The effects of UP on the flotation studied by many researchers using different coals, ores and minerals [27-50]. It has been concluded that UP increased the flotation recovery, reduced reagents consumption, and decreased the ash content. Most of the research work in flotation has been addressed to a better understanding of the variables affecting the separation. In the recent study related to zinc flotation [51] zinc recovery from lead-zinc-copper ore was higher by CF cell than MF. Nevertheless, much remains to be done regarding comparison of the effects of UP on the MF and CF. According to the knowledge of the authors no efforts were done to compare the effect of UP by using a laboratory ultrasound bath on the zinc flotation recovery from the same ore using MF and CF except for our works [1, 2]. Therefore, the aim of this work is to review and compare the effect of UP on the MF [1] and CF [2] performances in terms of $\mathrm{Zn}$ grade and recovery using the same ore. By this review study let's look for the answer to some questions like which one is more effective in terms of separation recovery and zinc grade? Secondly, is ultrasound really affecting on these two different beneficiation techniques positively? In other way of saying, does ultrasonic pretreatment aid to increase 
the separation recovery and zinc grade of the concentrates by mechanical flotation and column flotation using the same material.

The flotation conditions optimized for both flotation experiments were as follows: For MF tests [1], effects of Potassium Amyl Xanthate (KAX) describe it fully dosage, $\mathrm{CuSO}_{4}$ dosage, 2-ethyl hexanol dosage, residence time, stirring speed, and $\mathrm{Na}_{2} \mathrm{SiO}_{3}$ dosage on MF performance were tested to hold the optimum conditions. For the effects of UP on MF tests, $\mathrm{KAX}$ dosage, $\mathrm{CuSO}_{4}$ dosage, Aerofloat 211 dosage, $\mathrm{Na}_{2} \mathrm{SiO}_{3}$ dosage, 2-ethyl hexanol dosage, optimum flotation time and stirring speed on the MF performance were set as $90 \mathrm{~g} / \mathrm{t}, 400 \mathrm{~g} / \mathrm{t}, 100 \mathrm{~g} / \mathrm{t}, 50 \mathrm{~g} / \mathrm{t}, 15 \mathrm{~g} / \mathrm{t}, 4 \mathrm{~min}$., and $1000 \mathrm{rpm}$, respectively. The effects of each parameter on the MF tests were already described in detail by the previous study [1].

As for CF optimization tests [2], effects of KAX dosage, 2-ethyl hexanol dosage, residence time, stirring speed, $\mathrm{Na}_{2} \mathrm{SiO}_{3}$ dosage, superficial air rate, superficial wash water rate, and superficial feed rate on CF performance were tested and the fixed parameters for the effect of UP on the $\mathrm{CF}$ for both single and multistage zinc beneficiation were set as $400 \mathrm{~g} / \mathrm{t}$ of $\mathrm{CuSO}_{4}, 100 \mathrm{~g} / \mathrm{t}$ of Aerofloat 211, $15 \mathrm{~g} / \mathrm{t}$ of 2-ethyl hexanol, $50 \mathrm{~g} / \mathrm{t}$ of $\mathrm{Na}_{2} \mathrm{SiO}_{3}, 90 \mathrm{~g} / \mathrm{t}$ of KAX, $160 \mathrm{rpm}$ of stirring speed, $0.170 \mathrm{~cm} / \mathrm{sec}$ of superficial wash water rate, $0.425 \mathrm{~cm} / \mathrm{sec}$ of superficial feed rate, $1.5 \mathrm{~cm}$. sec of superficial air rate and $4 \mathrm{~min}$. of residence time. The comparison of the ultrasonic effect on the two different flotation techniques was accomplished by using a 12-liter laboratory-scale ultrasonic cleaning bath having $40 \mathrm{kHz}$ (power of 600 watt).

\section{Optimization of flotation for mechanical and column cells}

For comparative evaluation between MF and CF the same zinc samples $[1,2,51]$ was taken from zinc feed of the selective zinc flotation circuit plant (İvrindi-Balıkesir in Turkey) and treating lead-zinc-copper complex ore containing $\mathrm{Pb}, \mathrm{Cu}$, and $\mathrm{Zn}$ as $3.23 \%, 0.52 \%$, and $2.71 \%$, respectively. The XRD of the ore was given previously [1]. Particle size distribution (psd) of the samples used for this review is given in Fig. 1, which shows the whole particle size is below $74 \mu \mathrm{m}$. While MF experiments is shown in Fig. 2 [1] CF tests are illustrated by Fig. 3 [2].

Concentrate grade and recovery values at different operating conditions should be tested for inferring the optimal operating conditions for comparing flotation performance of the same ore tested for the effect of ultrasonic pretreatment on the mechanical and column cell for different conditions.

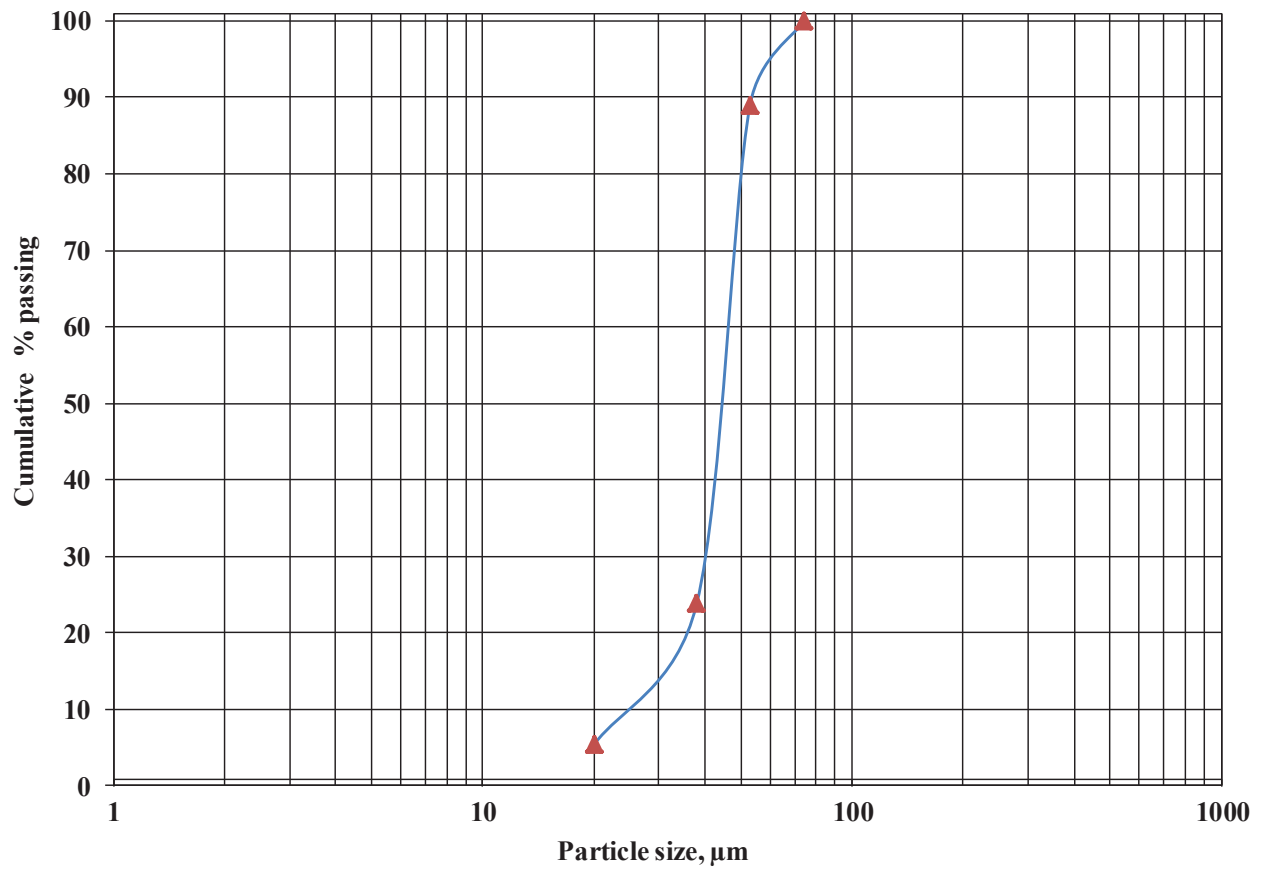

Fig. 1. Particle size distributions of the samples used in MF and CF tests (redrawn from [1, 2]) 


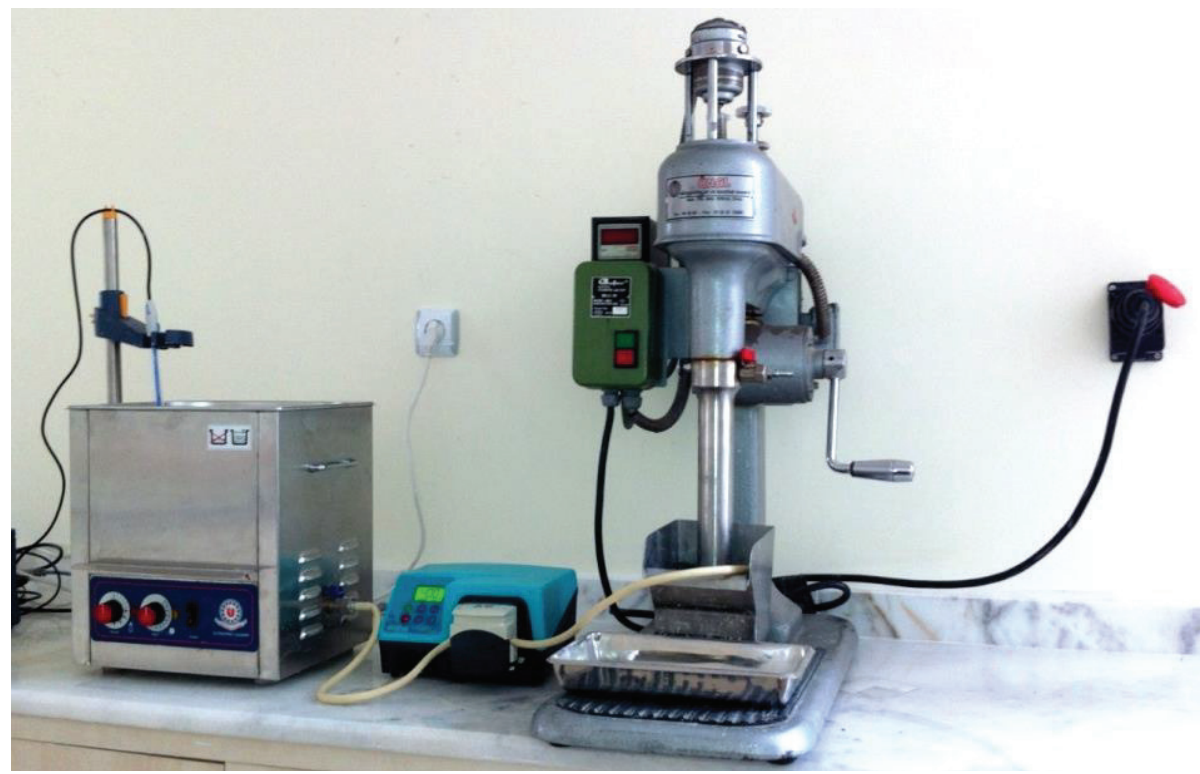

Fig. 2. Experimental setup used in MF tests with UP

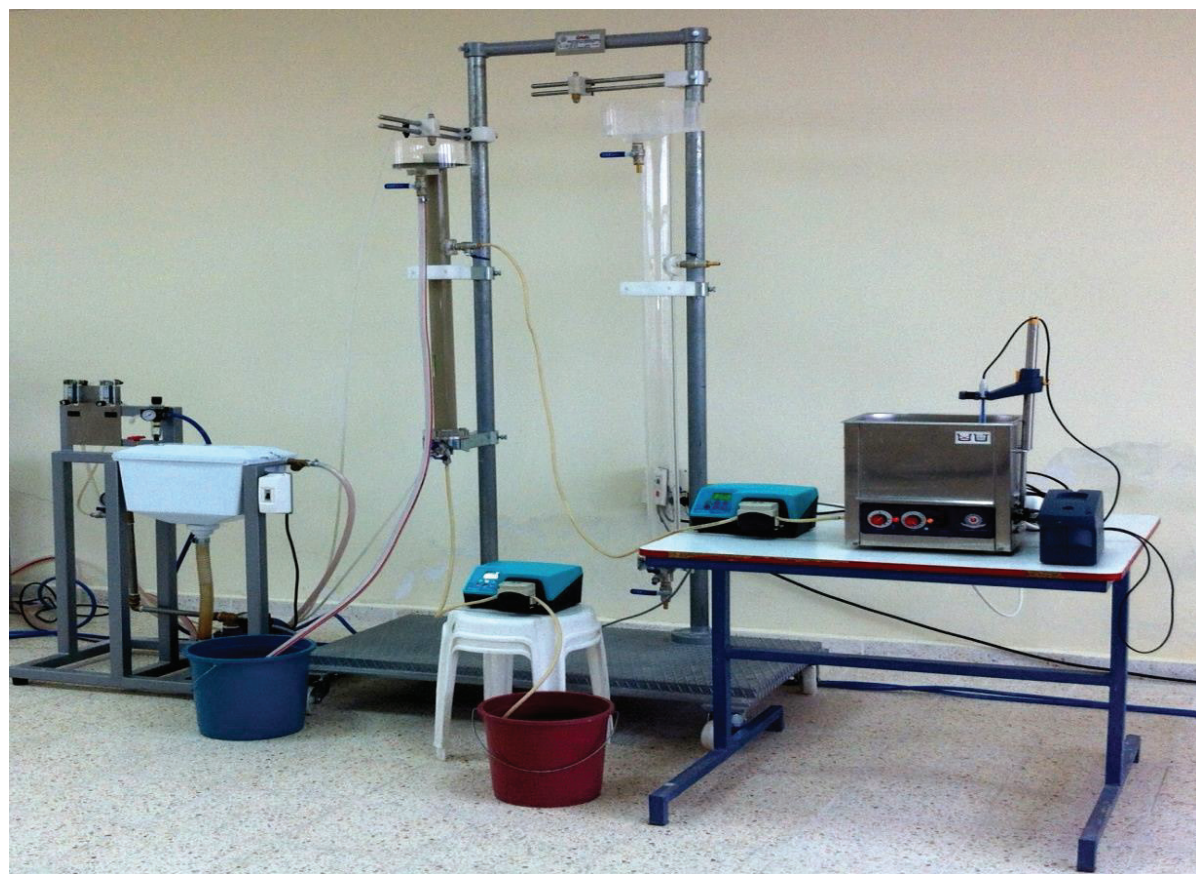

Fig. 3. Experimental setup used in CF tests with UP [2]

\section{Results and discussion}

As shown in Fig. 4, the zinc grade and recovery with MF followed by UP augmented $10.21 \%$ and $8.54 \%$, respectively. This result is in agreement with the previously published works $[29,37,49]$.

Results of X-ray diffraction patterns of the raw ore, MF concentrate without UP and MF concentrate with UP (Fig. 5, $\boldsymbol{a}-\boldsymbol{d}$ ) were also support this improvement. It should be noted that UP plays positive role on zinc content on MF since the highest sphalerite peaks were observed in MF concentrate with UP (Fig. 5, c) whereas the lowest Quartz peaks were observed in in Fig. 5, $c$ as clearly evident by the Fig. $\mathbf{5}, \boldsymbol{d}$, which represent all in one.

Since industrial flotation is a continuous and often multistage process, CF tests were also implemented by using 3 stages of batch cleaning and 3 stages of batch scavenging flotation expe- 
riments using the same laboratory column cell in this work. At the optimized CF conditions [2], single stage and multiple stages of CF with UP tests were conducted. Comparing the zinc grade and recovery values by single stage CF with and without UP (Fig. 4), the zinc grade was raised with 7.58 units while the recovery was enhanced by 10.56 units. When 3 stages of cleaning and 3 stages of scavenging CF experiments carried out, zinc grade of the final concentrate was increased 19.91 units. On the other hand, zinc recovery was increased 4.96 units. Therefore, this result indicates that by using UP with CF sphalerite mineral can be effectively recovered for marketable zinc concentrate product. These findings are in good agreement with the previously reported studies $[49,37,29,52]$.

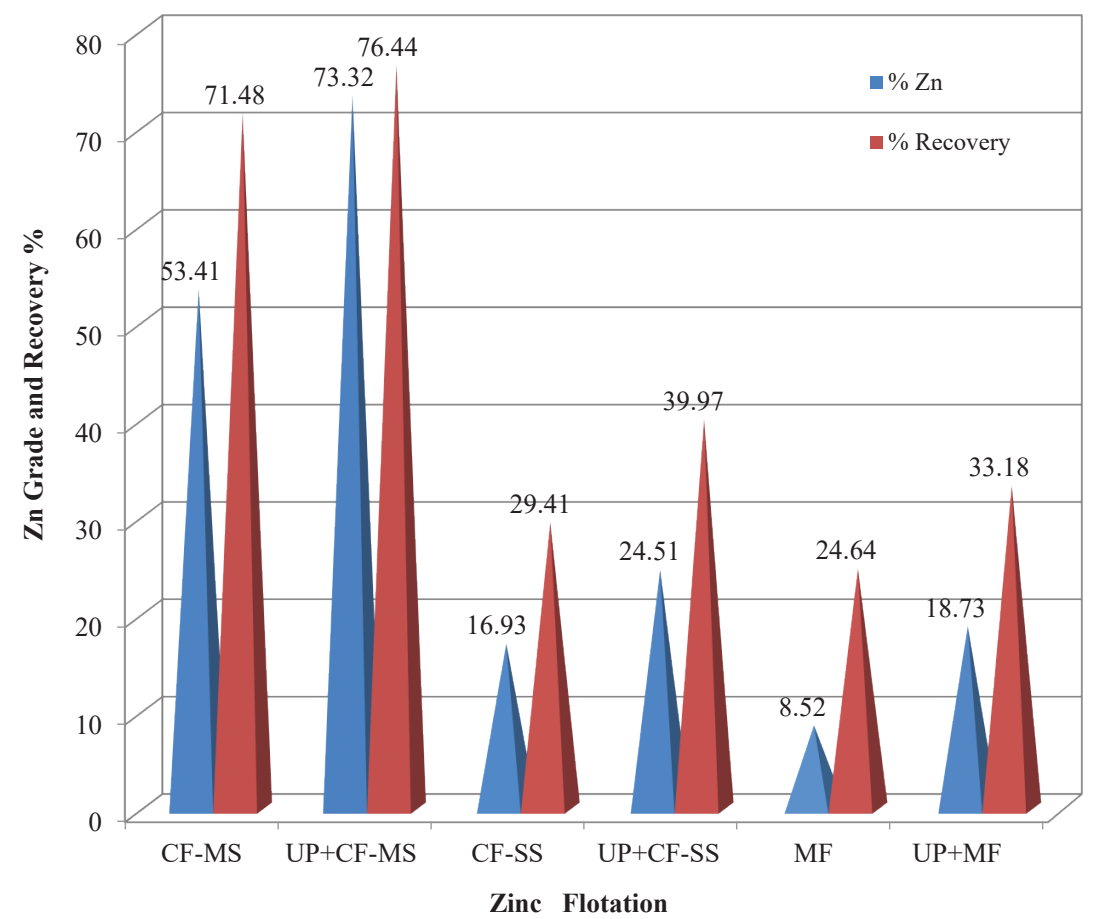

Fig. 4. Effect of UP on the performance of CF and MF in terms of zinc grade and recovery (redrawn from [1, 2]. (Here; $\boldsymbol{C F}-\mathbf{M S}$; Multi Stage Colum Flotation, UP+CF-MS; Multi Stage Colum Flotation with Ultrasonic Pre-treatment, CF-SS; Single Stage Colum Flotation, $\boldsymbol{U P}+\boldsymbol{C F}$-SS; Single Stage Colum Flotation with Ultrasonic Pre-treatment, MF; Mechanical Flotation, $\boldsymbol{U P}+\boldsymbol{M F}$; Mechanical Flotation with Ultrasonic Pre-treatment)

As shown in Fig. 6 increase in the superficial air rate augmented the zinc recovery in $\mathrm{CF}$, but diminished the zinc grade up to the values of $1.5 \mathrm{~cm} / \mathrm{sec}$. Bubbles were growth due to the coalescence (at superficial air rate values higher than $2.0 \mathrm{~cm} / \mathrm{sec}$.) intensive slurry stirring and collapsing as evidence by Fig. 7 showing air bubble images captured at different air rates. The bubbly flow conditions, which were preferred in CF were damaged and transformed to the churn-turbulent flow conditions as large bubbles indicates worsening of flotation process as proposed by [53].

Comparison of the $\mathrm{CF}$ and $\mathrm{MF}$ results indicated that zinc grade and recovery for $\mathrm{CF}$ was substantially higher than MF not surprisingly for the same ore tested in this work since the main advantage of the CF cells over MF ones is higher separation performance. Besides, MF cell use agitation mechanism while in CF air bubbles are produced by air spargers connected with a compressor and CF use wash water system to wash out the hydrophilic particles entrained into the froth zone, hence preventing their recovery to the concentrate in order to increase performance and selectivity. From Fig. 4, the zinc grade and recovery for both CF and MF with UP were higher than the zinc grade and recovery for both CF and MF without UP when UP was applied to both $\mathrm{CF}$ and MF cell. 

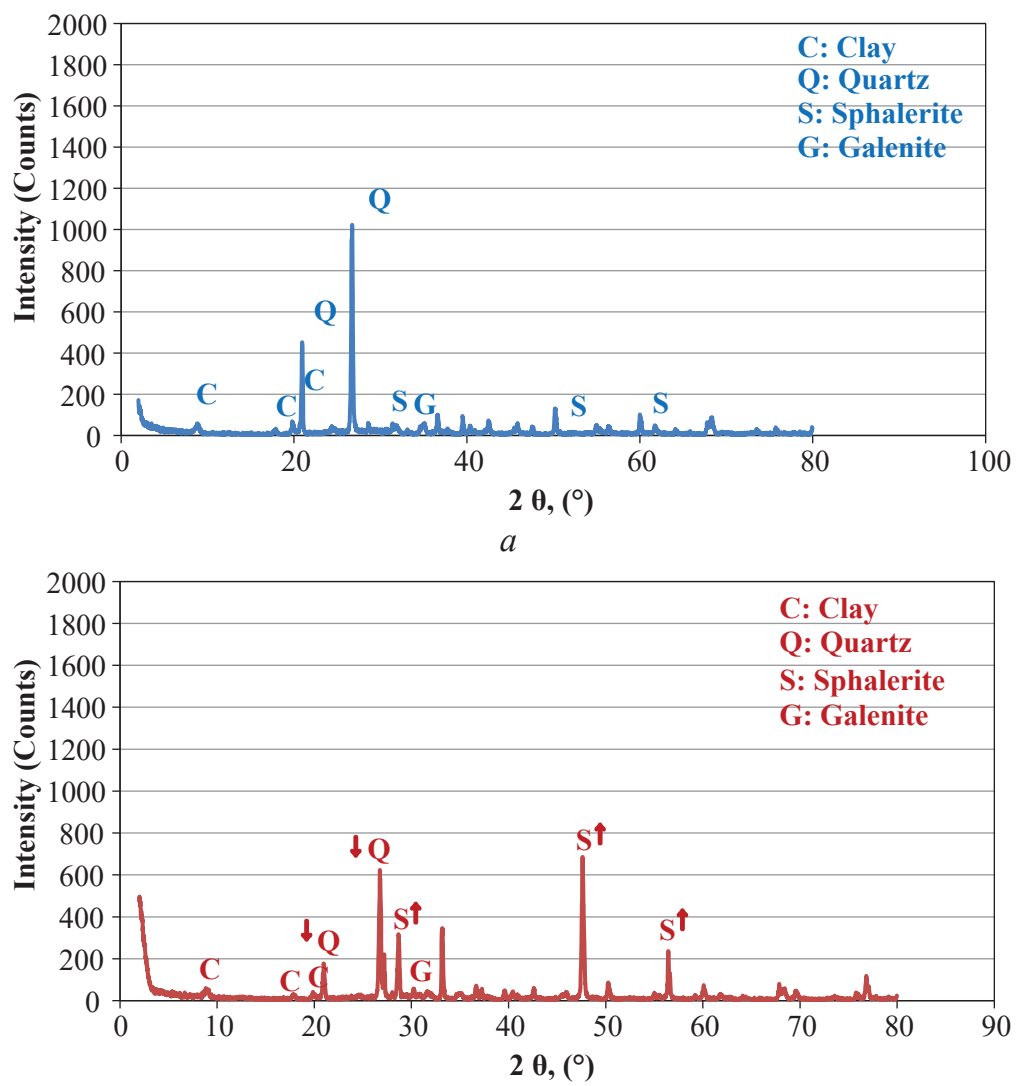

$b$
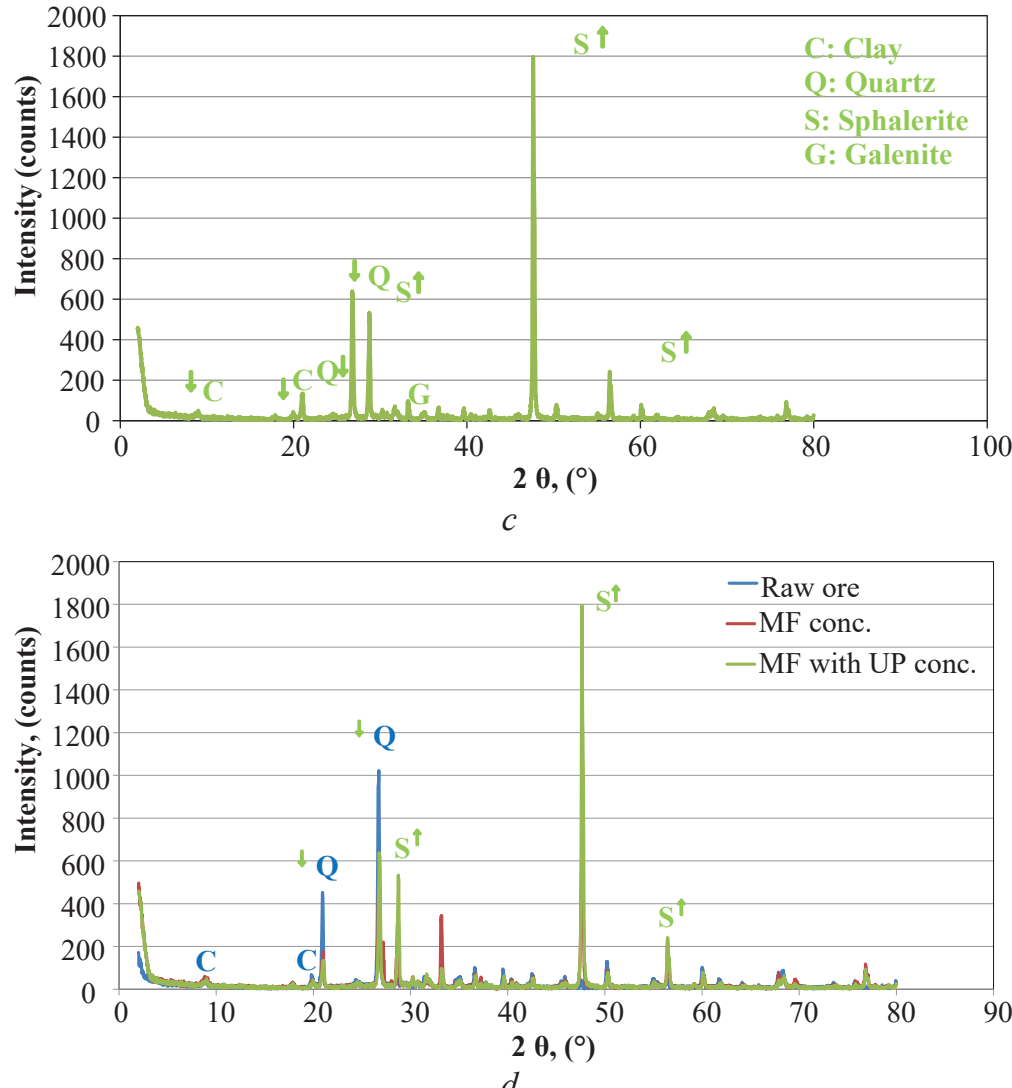

Fig. 5. XRD patterns:

$a$ - the raw ore; $b$ - concentrate of MF; $c$ - concentrate of MF with UP; $d$ - all in one [1] 


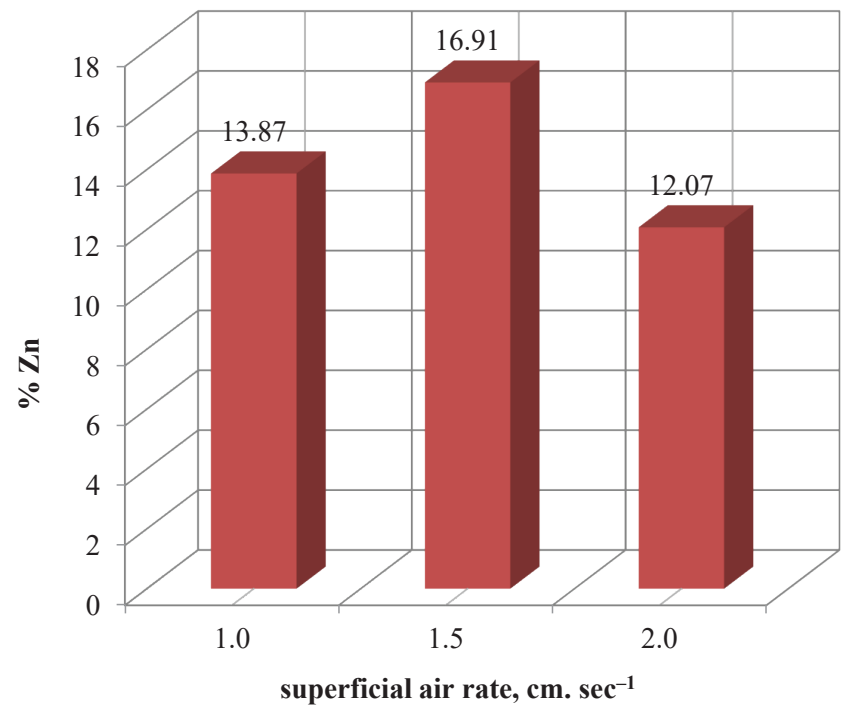

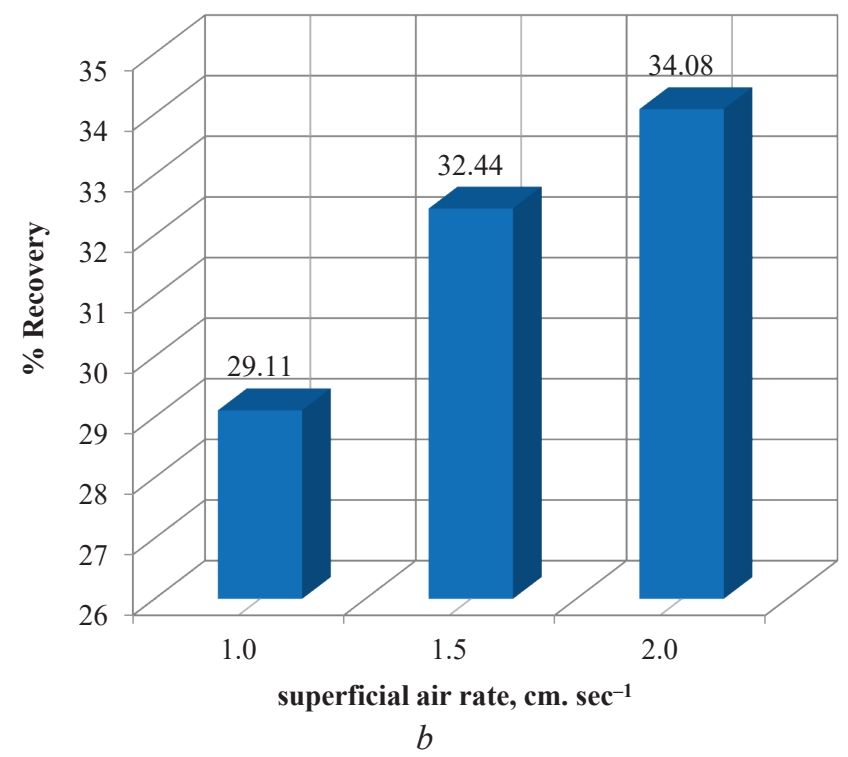

Fig. 6. Impacts of superficial air rate on the grade and recovery of zinc flotation in CF (redrawn from [2]): $a$ - grade; $b$ - recovery

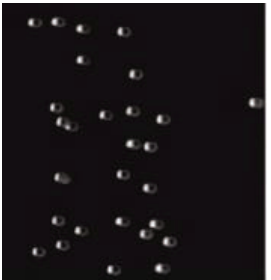

$a$

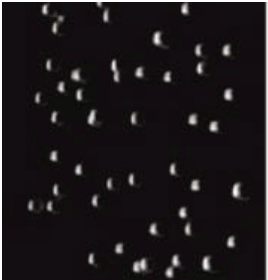

$b$

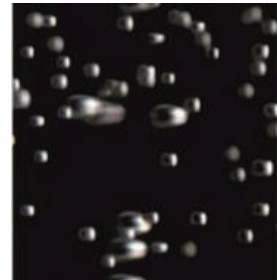

$c$

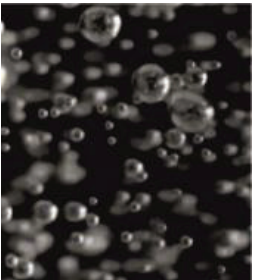

$d$

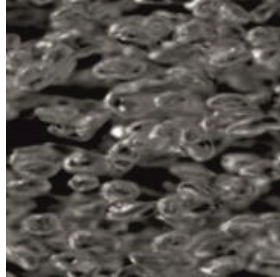

Fig. 7. Captured images of flotation bubbles at different air rates in the CF tests without UP (modified from [2]): $a-0.5 \mathrm{~cm} . \mathrm{sec}^{-1} ; b-1 \mathrm{~cm} . \mathrm{sec}^{-1} ; c-1.5 \mathrm{~cm} . \mathrm{sec}^{-1}$;

$$
d-2 \mathrm{~cm} . \mathrm{sec}^{-1} ; e->2 \mathrm{~cm} . \mathrm{sec}^{-1}
$$

Both improvements in the zinc grade and recovery may be attributed to the dispersing effects of ultrasound, increasing adsorption of collectors on the particle surfaces. It may also be due to the hydrodynamic cavitation, which produced small bubbles $[49,37,29,54,55,28]$ attaching to the hydrophobic particles and leading to the agglomeration of ultrafine particles by bubble bridging, making them as if they were larger particles of higher probability of attachment to the large bubbles in a flotation cell thereby increasing contact angle, attachment forces, the bubble-particle collision efficiency and better flotation recovery $[37,15,35]$. It has found that, ultrasonic treatment was good for the adsorption of collector molecules and increased the flotation yield by making fine particles hard to stick to the bubbles surfaces to improve the selectivity of fine particles [56]. Besides, ultrasound can raise the adsorption of cavitation bubbles on the particles and enhance the hydrophobicity of coal particle surface. In addition, micro bubbles were favored to adsorb on hydrophobic particle surface, which also amended hydrophobicity and heightened the efficiency of collision/adhesion between hydrophobic particles and air bubbles for higher flotation recovery rate. It has been also reported that, transient cavitation bubbles generate more fresh and hydrophobic surfaces on the particles surfaces to become profoundly cleaned and more easily picked by flotation $[57,58]$.

Fig. 8 shows bubble-particle aggregates formed by attachment of the small bubbles on the hydrophobic particles. The aggregation of sphalerite mineral particles by UP owing to cavitation effect is an indication of improved flotation efficiency. It supports the improvements in flotation performance $[55,29]$. Since the economic efficiency of the plant is assessed either by the net smelter return per ton of ore or the net revenue of the concentrator [59], flotation process with UP will 
produce a high-grade concentrate that maximizes an economic performance index, which may be as simple as the net revenue of the plant.

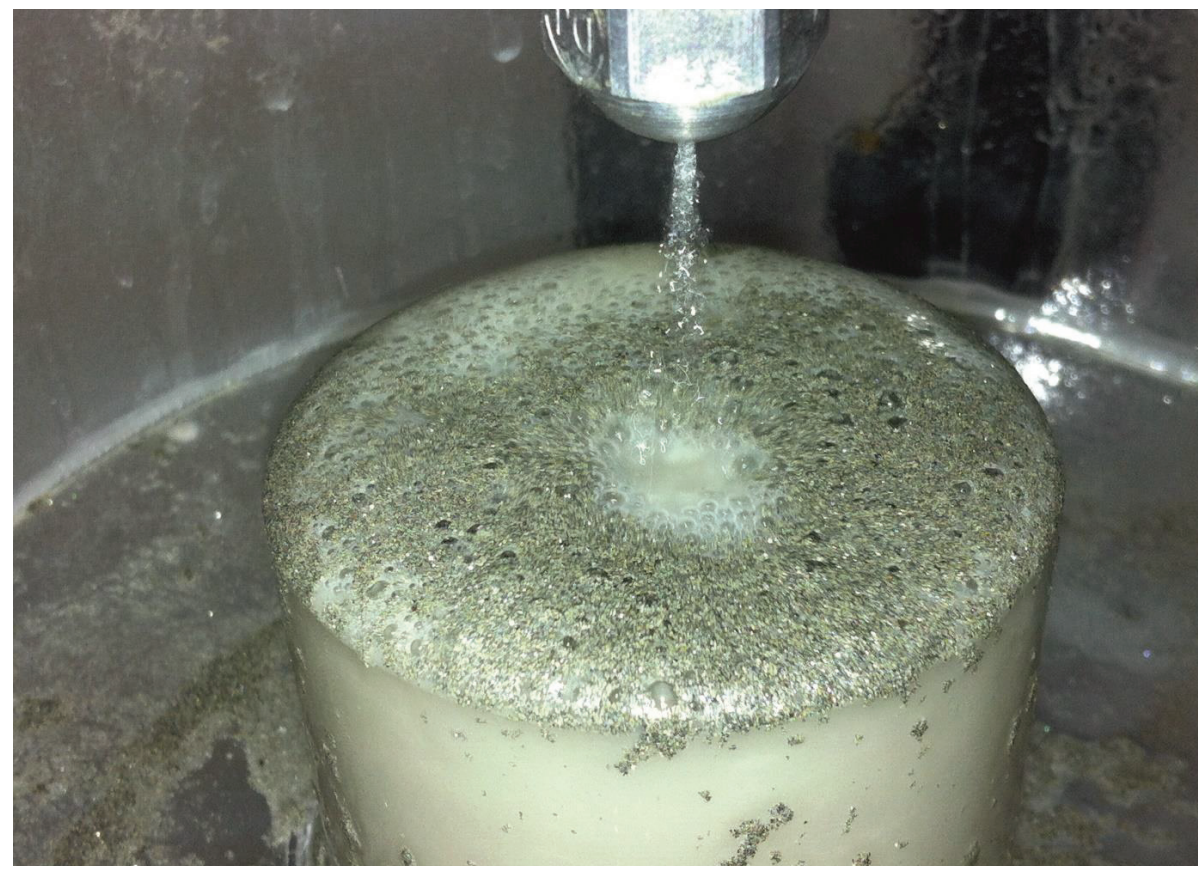

Fig. 8. The bubble-particle aggregates formed by in UP at CF tests (modified from [2])

The intensity of ultrasound would affect the degree of zinc recovery. Since there are all instruments at laboratory scale, cost estimation or techno-economic evaluation for this proposed process has not been considered in this study due to the insufficient information. The use of high power and continuous-type ultrasound need to be studied because they may enhance both MF and CF process. An economic assessment of the ultrasonic pretreatment methods must be made to determine their feasibility when designing an industrial mechanical and column flotation processes.

\section{Conclusions}

Since CF has an advantage in recovering of fine particles than MF because of more favorable conditions and smaller bubbles. The small bubbles can be produced by using UP with CF. So, zinc grade and recovery for $\mathrm{CF}$ at single stage and multistage was substantially higher than MF of zinc flotation.

In fact, $\mathrm{CF}$ is known to provide higher concentration, more productivity, less cost of production, and better control of plant than the conventional MF owing to the long retention time of the solid particles, counter current flow, contact pattern and the wash water added at the top of the froth.

Above all, UP increased zinc grade and recovery for both MF and CF techniques as supported by XRD patterns. Considering great tonnage of ores is being processed by flotation, any increments in the flotation recovery will make noteworthy profits. Besides, UP with CF will lead to a higher metallurgical gains and improvements to Net Smelter Return (NSR).

The contribution effect of ultrasound, which is safe and eco-friendly, on the flotation performance may because of increasing dispersion, increasing adsorption of collectors and generation of more fresh and hydrophobic surfaces. So that hydrodynamic cavitation, produces small bubbles attaching to the hydrophobic particles to increase contact angle and attachment forces causing bubble-particle collision efficiency and better flotation recovery.

This review introduces UP as one of the bright and sustainable method for amending flotation of zinc ores. 


\section{Acknowledgments}

Thanks are extended to the operating manager of GESOM A. Ş. for providing ore samples. The authors express appreciation to Prof. Dr. Murat Erdemoğlu and Prof. Dr. HüseyinYalçın for their help in XRD analysis and interpretation.

\section{References}

[1] Kursun, H. (2014). A Study on the Utilization of Ultrasonic Pretreatment in Zinc Flotation. Separation Science and Technology, 49 (18), 2975-2980. doi: https://doi.org/10.1080/01496395.2014.941876

[2] Kursun, H., Ulusoy, U. (2014). Zinc Recovery from a Lead-Zinc-Copper Ore by Ultrasonically Assisted Column Flotation. Particulate Science and Technology, 33 (4), 349-356. doi: https://doi.org/10.1080/02726351.2014.970314

[3] Barma, S. D. (2019). Ultrasonic-assisted coal beneficiation: A review. Ultrasonics Sonochemistry, 50, 15-35. doi: https://doi.org/ 10.1016/j.ultsonch.2018.08.016

[4] Renken, P. (2011). Zinc. Mining Commodity report. VSA Capital, London.

[5] Zinc Statistics and Information. Available at: https://www.usgs.gov/centers/nmic/zinc-statistics-and-information

[6] Zinc (2020). Mineral Commodity Summaries. Available at: https://pubs.usgs.gov/periodicals/mcs2020/mcs2020-zinc.pdf

[7] Koh, P., Smith, L. (2010). Experimental validation of a flotation cell model. XXV International Mineral Processing Congress (IMPC) 2010 Proceedings. Brisbane.

[8] Stassen, F. J. N. (1991). Conditioning in the flotation of gold, uranium oxide and pyrite. Journal of the Southern African Institute of Mining and Metallurgy, 91 (5), 169-174.

[9] Bulatovic, S. M., Salter, R. S. (1989). High intensity conditioning - a new approach to improving flotation of mineral slimes. Processing of Complex Ores, 169-181. doi: https://doi.org/10.1016/b978-0-08-037283-9.50020-2

[10] Rubio, J., Brum, I. (1994). The conditioning effect on the flotation of copper/molybdenum mineral particles. In Proceedings Southern Hemisphere Meeting on Mineral Technology, 4, Concepción-Chile, Proceedings, 2, 295-308.

[11] Aldrich, C., Feng, D. (1999). Effect of ultrasonic preconditioning of pulp on the flotation of sulphide ores. Minerals Engineering, 12 (6), 701-707. doi: https://doi.org/10.1016/s0892-6875(99)00053-9

[12] Teipel, U., Leisinger, K., Mikonsaari, I. (2004). Comminution of crystalline material by ultrasonics. International Journal of Mineral Processing, 74, S183-S190. doi: https://doi.org/10.1016/j.minpro.2004.07.011

[13] Leonelli, C., Mason, T. J. (2010). Microwave and ultrasonic processing: Now a realistic option for industry. Chemical Engineering and Processing: Process Intensification, 49 (9), 885-900. doi: https://doi.org/10.1016/j.cep.2010.05.006

[14] 5 Key Points to Selecting the Correct Ultrasonic Cleaner Size. Available at: http://www.tovatech.com/ultrasonic-cleaner/ how-ultrasonics-works.php

[15] Zhou, Z. A., Xu, Z., Finch, J. A., Hu, H., Rao, S. R. (1997). Role of hydrodynamic cavitation in fine particle flotation. International Journal of Mineral Processing, 51 (1-4), 139-149. doi: https://doi.org/10.1016/s0301-7516(97)00026-4

[16] Khanal, S. K., Grewell, D., Sung, S., van Leeuwen, J. (Hans) (2007). Ultrasound Applications in Wastewater Sludge Pretreatment: A Review. Critical Reviews in Environmental Science and Technology, 37 (4), 277-313. doi: https://doi.org/ 10.1080/10643380600860249

[17] Basedow, A. M., Ebert, K. H. (1977). Ultrasonic degradation of polymers in solution. Advances in Polymer Science, 83-148. doi: https://doi.org/10.1007/3-540-07942-4_6

[18] Subrahmanyam, T. V., Forssberg, K. S. E. (1990). Fine particles processing: shear-flocculation and carrier flotation - a review. International Journal of Mineral Processing, 30 (3-4), 265-286. doi: https://doi.org/10.1016/0301-7516(90)90019-u

[19] Song, S., Lopez-Valdivieso, A., Reyes-Bahena, J. L., Lara-Valenzuela, C. (2001). Floc flotation of galena and sphalerite fines. Minerals Engineering, 14 (1), 87-98. doi: https://doi.org/10.1016/s0892-6875(00)00162-X

[20] Finch, J. A., Dobby, G. S. (1990). Column flotation. Oxford: Pergamon Press.

[21] Somasundaran, P. (1986). An Overview of the Ultrafine Problem. Mineral Processing at a Crossroads, 1-36. doi: https://doi.org/ 10.1007/978-94-009-4476-3_1

[22] Kawatra, S. K., Eisele, T. C. (1987). Column Flotation of Coal. In Fine Coal Processing, Klimpel, Noyes, Park Ridge, New Jersey, 414-426.

[23] Demers, I. (2005). Enhancing fine particle recovery in flotation and its potential application to the environmental desulphurization process. University of Quebec.

[24] Farmer, A. D., Collings, A. F., Jameson, G. J. (2000). Effect of ultrasound on surface cleaning of silica particles. International Journal of Mineral Processing, 60 (2), 101-113. doi: https://doi.org/10.1016/s0301-7516(00)00009-0

[25] Zhao, H. L., Wang, D. X., Cai, Y. X., Zhang, F. C. (2007). Removal of iron from silica sand by surface cleaning using power ultrasound. Minerals Engineering, 20 (8), 816-818. doi: https://doi.org/10.1016/j.mineng.2006.10.005 
[26] Farmer, A. D., Collings, A. F., Jameson, G. J. (2000). The application of power ultrasound to the surface cleaning of silica and heavy mineral sands. Ultrasonics Sonochemistry, 7 (4), 243-247. doi: https://doi.org/10.1016/s1350-4177(00)00057-2

[27] Ślączka, A. (1987). Effects of an ultrasonic field on the flotation selectivity of barite from a barite-fluorite-quartz ore. International Journal of Mineral Processing, 20 (3-4), 193-210. doi: https://doi.org/10.1016/0301-7516(87)90066-4

[28] Gurpinar, G., Sonmez, E., Bozkurt, V. (2004). Effect of ultrasonic treatment on flotation of calcite, barite and quartz. Mineral Processing and Extractive Metallurgy, 113 (2), 91-95. doi: https://doi.org/10.1179/037195504225005796

[29] De F. Gontijo, C., Fornasiero, D., Ralston, J. (2008). The Limits of Fine and Coarse Particle Flotation. The Canadian Journal of Chemical Engineering, 85 (5), 739-747. doi: https://doi.org/10.1002/cjce.5450850519

[30] Celik, M. S. (1989). Effect of Ultrasonic Treatment on the Floatability of Coal and Galena. Separation Science and Technology, 24 (14), 1159-1166. doi: https://doi.org/10.1080/01496398908049894

[31] Feng, D., Aldrich, C. (2004). Effect of Ultrasonication on the Flotation of Talc. Industrial \& Engineering Chemistry Research, 43 (15), 4422-4427. doi: https://doi.org/10.1021/ie034057g

[32] Ozkan, S. G. (2002). Beneficiation of magnesite slimes with ultrasonic treatment. Minerals Engineering, 15 (1-2), $99-101$. doi: https://doi.org/10.1016/s0892-6875(01)00205-9

[33] Franko, J., Klima, M. S. (2002). Application of ultrasonics to enhance wet-drum magnetic separator performance. Mining, Metallurgy \& Exploration, 19 (1), 17-20. doi: https://doi.org/10.1007/bf03402895

[34] Pandey, J. C., Sinha, M., Raj, M. (2010). Reducing alumina, silica and phosphorous in iron ore by high intensity power ultrasound. Ironmaking \& Steelmaking, 37 (8), 583-589. doi: https://doi.org/10.1179/030192310x12731438632083

[35] Misra, M., Raichur, A. M., Lan, A. P. (2003). Improved flotation of arsenopyrite by ultrasonic pretreatment. Mining, Metallurgy \& Exploration, 20 (2), 93-97. doi: https://doi.org/10.1007/bf03403138

[36] Zhou, Z. A. (1996). Gas nucleation and cavitation in flotation. McGill University.

[37] Zhou, Z. A., Xu, Z., Finch, J. A. (1994). On the role of cavitation in particle collection during flotation - a critical review. Minerals Engineering, 7 (9), 1073-1084. doi: https://doi.org/10.1016/0892-6875(94)00053-0

[38] Zhou, Z. A., Xu, Z., Finch, J. A. (1995). Fundamental study of cavitation in flotation. In: XIX International Mineral Processing Congress. Vol. 3. San Francisco, 93-97.

[39] Cilek, E. C., Ozgen, S. (2010). Improvement of the Flotation Selectivity in a Mechanical Flotation Cell by Ultrasound. Separation Science and Technology, 45 (4), 572-579. doi: https://doi.org/10.1080/01496390903484966

[40] Nicol, S. K., Engel, M. D., Kee Chye Teh. (1986). Fine-particle flotation in an acoustic field. International Journal of Mineral Processing, 17 (1-2), 143-150. doi: https://doi.org/10.1016/0301-7516(86)90052-9

[41] Buttermore, W. H., Slomka, B. J. (1991). The effect of sonic treatment on the flotability of oxidized coal. International Journal of Mineral Processing, 32 (3-4), 251-257. doi: https://doi.org/10.1016/0301-7516(91)90071-p

[42] Attalla, M., Chao, C., Nicol, S. K. (2000). The role of cavitation in coal flotation. In Proc. of the 8th Australian Coal Preparation Conference, Port Stephens, NSW. Australian Coal Preparation Society, 337-350.

[43] Jun, H., Dian-Zuo, W., Yong-Ping, H. (2002). Research on coal flotation by co-action of reagents and ultrasonic wave treatment. Journal of China University of Mining \& Technology, 31 (2), 186-189.

[44] Ozkan, S. G., Kuyumcu, H. Z. (2006). Investigation of mechanism of ultrasound on coal flotation. International Journal of Mineral Processing, 81 (3), 201-203. doi: https://doi.org/10.1016/j.minpro.2006.07.011

[45] Ozkan, Ş. G., Kuyumcu, H. Z. (2007). Design of a flotation cell equipped with ultrasound transducers to enhance coal flotation. Ultrasonics Sonochemistry, 14 (5), 639-645. doi: https://doi.org/10.1016/j.ultsonch.2006.10.001

[46] Kang, W., Xun, H., Hu, J. (2008). Study of the effect of ultrasonic treatment on the surface composition and the flotation performance of high-sulfur coal. Fuel Processing Technology, 89 (12), 1337-1344. doi: https://doi.org/10.1016/j.fuproc.2008.06.003

[47] Ozkan, S. G. (2012). Effects of simultaneous ultrasonic treatment on flotation of hard coal slimes. Fuel, 93, 576-580. doi: https:// doi.org/10.1016/j.fuel.2011.10.032

[48] Tao, Y., Liu, J., Yu, S., Tao, D. (2006). Picobubble Enhanced Fine Coal Flotation. Separation Science and Technology, 41 (16), 3597-3607. doi: https://doi.org/10.1080/01496390600957249

[49] Qi, B. C., Aldrich, C. (2002). Effect of ultrasonic treatment on zinc removal from hydroxide precipitates by dissolved air flotation. Minerals Engineering, 15 (12), 1105-1111. doi: https://oi.org/10.1016/s0892-6875(02)00261-3

[50] Feng, D., Aldrich, C. (2005). Effect of Preconditioning on the Flotation of Coal. Chemical Engineering Communications, 192 (7), 972-983. doi: https://doi.org/10.1080/009864490521534

[51] Kursun, H., Ulusoy, U. (2012). Zinc Recovery From Lead-Zinc-Copper Complex Ores by Using Column Flotation. Mineral Processing and Extractive Metallurgy Review, 33 (5), 327-338. doi: https://doi.org/10.1080/08827508.2011.601479

[52] Gungoren, C., Ozdemir, O., Ozkan, S. G. (2017). Effects of temperature during ultrasonic conditioning in quartz-amine flotation. Physicochemical Problems of Mineral Processing, 53 (2), 687-698. doi: http://doi.org/10.5277/ppmp170201 
[53] Burstein, M., Filippov, L. (2010). Scale-up of Flotation Processes. Publication Number: CSRCR2010-01. Computational Science Research Center, San Diego State University, San Diego.

[54] Oliveira, H., Azevedo, A., Rubio, J. (2018). Nanobubbles generation in a high-rate hydrodynamic cavitation tube. Minerals Engineering, 116, 32-34. doi: https://doi.org/10.1016/j.mineng.2017.10.020

[55] Zhou, Z. A., Xu, Z., Finch, J. A., Masliyah, J. H., Chow, R. S. (2009). On the role of cavitation in particle collection in flotation - A critical review. II. Minerals Engineering, 22 (5), 419-433. doi: https://doi.org/10.1016/j.mineng.2008.12.010

[56] Mao, Y., Peng, Y., Bu, X., Xie, G., Wu, E., Xia, W. (2018). Effect of ultrasound on the true flotation of lignite and its entrainment behavior. Energy Sources, Part A: Recovery, Utilization, and Environmental Effects, 40 (8), 940-950. doi: https://doi.org/ 10.1080/15567036.2018.1466009

[57] Chen, Y., Truong, V. N. T., Bu, X., Xie, G. (2020). A review of effects and applications of ultrasound in mineral flotation. Ultrasonics Sonochemistry, 60, 104739. doi: https://doi.org/10.1016/j.ultsonch.2019.104739

[58] Zheng, C., Ru, Y., Xu, M., Zhen, K., Zhang, H. (2018). Effects of ultrasonic pretreatment on the flotation performance and surface properties of coking middlings. Energy Sources, Part A: Recovery, Utilization, and Environmental Effects, 40 (6), 734-741. doi: https://doi.org/10.1080/15567036.2018.1457740

[59] Sosa-Blanco, C., Hodouin, D., Bazin, C., Lara-Valenzuela, C., Salazar, J. (2000). Economic optimisation of a flotation plant through grinding circuit tuning. Minerals Engineering, 13 (10-11), 999-1018. doi: https://doi.org/10.1016/s0892-6875(00)00086-8 